\section{Output Growth Volatility and Remittances: The Case of ECOWAS}

\author{
Deekor, Leelee Nwibari (Corresponding author) \\ Department of Economics, Ignatius Ajuru University of Education, \\ Port Harcourt, Nigeria \\ E-mail: duabari@yahoo.co.uk
}

Gbanador, Clever A.

Department of Economics, University of Port Harcourt

Nigeria

Received: December 6, 2017 Accepted: June 5, 2018 Published: August 25, 2018

doi:10.5296/ijssr.v6i2.12647ＵRL: http://dx.doi.org/10.5296/ijssr.v6i2.12647

\begin{abstract}
The study on output growth volatility and remittances: the case of ECOWAS is to determine the impact of remittances on output growth volatility. To achieve this, the study adopts the theory of altruism which posits that the migrant derives a positive utility from the well-being of the family left behind. A panel annual data set covering 15 remittances recipient ECOWAS member nations for the period ranging from 1995 to 2015 were utilized. The study utilizes a panel system Generalized Method of Moments (GMM) technique and both the static and dynamic panel estimation approaches to examine the impact of remittances on growth volatility. Results show that remittances appear to be inducing output volatility in ECOWAS member countries. As a result, the study suggests among others, the encouragement of policies that will foster increasing influx of remittances to the region by the concern authorities in order to stabilize volatility of any form in the region.
\end{abstract}

Keywords: output-growth, volatility, remittance, System-GMM, ECOWAS

\section{Introduction}

Economic growth and development processes in the world are affected by migration of people. To this end, issues about the migration flows from the view point of the home countries have been centered on workers' remittances. The World Bank (2013) estimated that, 
in 2013 worldwide official record of remittance flows reached $\$ 550$ billion, with developing countries receiving the greater percentage of these flows ( $\$ 414$ billion). Theoretically, remittances can spur on financial growth through channels such as facilitating the economic market development, serving as a source of finance for entrepreneurial activities, insurance or coverage against shocks, financing household expenditure, financing of family capital formation, bridging financial savings hole and the external gap of financing. This has been empirically proven by a section of literature that has documented the positive gains of remittances for the recipient households. However, it is also possible that remittances affect economic fluctuations or output volatility, but in contrast to a considerable range of literatures that have discussed the effect of remittances on development and growth in developing nations, the impact of remittances on output growth fluctuation is almost negligible.

While the destructive impact of high output fluctuation on economic growth was first discussed by Ramey and Ramey (1995), and output volatility has also been identified to have direct adverse effect on welfare, particularly where opportunities for consumption smoothing are limited. Most economists tend to agree that there exist multiple pathways through which remittances can influence output volatility, and these pathways imply contradictory effects. Specifically, remittances can reduce or increase output volatility depending on the motivation of the remitter, which could be altruism in nature or driven by self-interest. However, the problem of whether a huge role of remittance receipts tends on the average to be stabilizing or otherwise is therefore a critical one, especially in the context of developing nations, wherein both growth and balance objectives are adequately valued. The rates and ranges of officially recorded remittances to growing economies appear to have increased greatly over the past decade, yet academic and policy-oriented researches have not reached a consensus over whether remittance increases or reduces output growth volatility.

Building on the aforementioned premise, this prevailing study is therefore a modest attempt to look at the effect of remittance income on output growth fluctuations of the Economic Community of West African States (ECOWAS). The contribution of this research to the literature goes beyond documenting output volatility and remittance relationship in ECOWAS region of African continent, but to provide in addition, an empirical knowledge of the impact of remittance on output volatility. In addition to their extremely vulnerability to adverse exogenous shocks, the ECOWAS member nations particularly Nigeria, Ghana, Cote D'Ivoire, Liberia, Benin, Togo, Mali, Senegal, Guinea, Guinea Bissau, Niger, Gambia, Burkina Faso, Cape Verde Sierra Leone have their migrant workers spread almost all over the world and thus remain among others an essential source of migrant workers for countries and continents suffering from labour shortages. Following this introductory section, the remaining sections of the paper are partitioned into six. Section 2 presents a literature evaluation while section 3 deals with the theoretical framework. Section 4 discusses the data and also provides some preliminary analyses. Section 5 is the econometric methodology; section 6 discusses the empirical results while the conclusion, policy recommendations are in section 7.

\section{Literature Review}

Existing empirical studies on remittances can be classified into two strands of literature 
which include, studies centered on the determinants of remittances, while the other are literatures that focus on the economic impact of remittances utilizing various economic variables consisting of growth, saving, income inequality, social indicators among others. The study by Lucas and Stark (1985) despite its outdated methodology remains a prime exemplar of the first type of empirical studies on remittances. Recent studies in the realm of the second position of the literature can be further categorized into two to include people who have investigated growth effect of remittances by applying the traditional global growth models and the other that used country specific analysis of remittances and growth relationship. However, empirical studies related to macroeconomic consequences of remittances appear to be scanty and considerable attentions have not yet been directed in the area of output volatility. The first trial to link remittances and macroeconomic stability is seen in IMF (2005), which discovers lower volatility of total output, consumption and investment in countries with large remittance inflows.

Bugamelli and Paternò, (2005, 2008), Ahamada and Coulibaly (2011), Ajide, Raheem and Adeniyi (2015) among other few notable studies provided empirical evidences on remittances and output fluctuation nexus in recent time. Findings from each of the respective studies have proved empirically that remittances are inversely correlated to output growth fluctuations and thus acknowledged growth volatility lowering impact of remittances. Contrary to the extant literature however, their finding suggests that, growth volatility reduction potential of remittances is highly pronounced in the presence of well-functioning institutions. Furthermore, Chami, Barajas, Cosimano, Fullenkamp, Gapen and Montiel (2008), Craigwell, Jackman and Moore (2009) find that remittances help to reduce growth volatility. However, Bettin, Presbitero and Spatafora (2014) findings show that on the other hand, remittances are inversely correlated with the business cycle in recipient countries, and again positively correlated with economic conditions in the source province. For Neagu and Schiff (2009) using a sample of 116 countries, they find that remittance flows have been destabilizing or have had no impact on output volatility in 80 percent of the nations examined.

\section{Theoretical Framework}

One important intuitive motivation for remitting money back home is what has been characterized in the literature as "altruism": the migrants' concern about relatives left in the home country. The theory of altruism posits that the migrant derives a nice utility from the well-being or consumption situation of the family at home (Becker 1974; Stark 1991). Based on this, the altruistic model predicts a corresponding relationship between the immigrant's earnings and the adverse conditions of the receiving family and an inverse relationship with the recipient household's income (Funkhouser 1995). The implication is that migrants have a strong desire to compensate the members of their households to offset or prevent income shortfalls caused by the economic fluctuations or external shocks in the home country. This is why altruism-motivated remittances are considered compensatory transfers; as such transfers enable recipient households to smooth their consumption over time. If flows are huge enough, remittances ought to reduce macroeconomic volatility of the receiving country. It is essential to note that remittances as compensatory transfers will raise the household income at times when the recipients' economies are in the downturn phase of their cycle, which is why 
altruism-motivated remittances exhibit a countercyclical behaviour.

\section{Data Description and Preliminary Analysis}

A balanced panel annual data set covering 15 remittances recipient ECOWAS member nations for the period ranging from 1995-2015 were utilized. The scope of the study is based on data availability. Data utilized are sourced from two main data banks namely the World Development Indicators (WDI) and databank of the International Financial Statistics (IFS). Output growth volatility is defined as the standard deviation of gross domestic product (GDP) per capita growth within 1995-2015. Per capita real GDP growth is measured using data on real per capita GDP in constant dollars (international prices, base year 2000). Ramey and Ramey (1995), Chami et al. (2012) and Ajide et al. (2015) are some of the studies which defined output volatility in the same way. Personal remittances are defined independently of the source of income of the sending household, the relationship between the households and the purpose for which the transfer is made. The set of manipulating variables employed consists of a wide array of variables that have been globally used and acknowledged in the empirical growth literature. These set of manipulating variables includes Capital Flows (CFLOW) which is the ratio of foreign direct investment (FDI) to GDP, Trade Openness (TOP) measured as sum of export and import to GDP, government consumption (GCON) is measured as ratio of final government consumption expenditure to GDP and Inflation rate (INFL) is measured as annual inflation rate.

The descriptive statistics for output growth fluctuation and its determinants covering the mean, standard deviation with corresponding minimum and maximum statistics are represented in Table 1, where average output growth volatility in ECOWAS region of Africa is $5.4 \%$ for the period considered. The evidence of significant variations between the minimum and maximum values of the series further makes the existence of volatility in this series more explicit. More so, when compare to capital flow, inflation rate and trade openness, remittance as exhibited by its standard deviation, records the lowest dispersion from the mean level. This among others may be taken as indicative of the relative importance of remittance in stabilizing output growth volatility. However, the huge dispersion between the mean and standard deviation values of capital flow, government consumption, inflation rate, and trade openness respectively can equally be taken as indication that these set of manage variables may have the tendency of inducing output volatility instead.

Table 1. Descriptive statistics

\begin{tabular}{|c|c|c|c|c|}
\hline Variable & Mean & Standard. Dev. & Minimum & Maximum \\
\hline GROWTH $_{\text {VOLT }}$ & 5.4047 & 7.6689 & 0.4784 & 45.3487 \\
\hline REM & 5.2269 & 4.5286 & 0.0200 & 23.4104 \\
\hline CFLOW & 4.8911 & 11.3324 & -0.7008 & 91.0073 \\
\hline GCON & 12.1489 & 4.2679 & 3.5878 & 25.7939 \\
\hline INFL & 25.7939 & 10.6389 & -3.5026 & 72.8355 \\
\hline TOP & 67.6107 & 21.6482 & 30.7325 & 179.1200 \\
\hline
\end{tabular}

Source: Authors Computation. 


\section{Model Specification and Methodological Framework}

The study utilizes the conventional growth model structure for specifying Ramey and Ramey (1995) output volatility model as cited in Ajide et al. (2015), which can be symbolically represented as follows:

$$
G D P_{V O L_{i, t}}=\alpha_{0}+\beta_{1} R E M_{i, t}+Z^{\prime} \gamma+\mu_{i}+\varepsilon_{i t}
$$

Equation (1) is meant to evaluate the direct effect of remittances on output growth volatility, where the number countries is $i=1, \mathrm{~K}, N$; the number of periods is $t=1, \mathrm{~K}, T ; G D P_{V O L_{i, t}}$ denotes output volatility while $Z$ is a $k \times 1$ vector of control variables. The latter includes Capital Flows $(C F L O W)$, Trade Openness $\left(T O P_{i, t}\right)$, Inflation Rate $\left(I N F L_{i, t}\right)$ and Government Consumption $\left(G C O N_{i, t}\right)$. The regression parameters are $\alpha_{0}, \beta_{1}$, and $\gamma$ (which denotes $a 1 \times k$ vector of parameters on the control variables); $\mu_{i}$ is the country-specific effect while $\varepsilon_{i t}$ is the regression disturbance term.

Essentially, we are interested in the sign of $\beta_{1}$ which is the coefficient of remittances inflow

(REM) in equation (1). If our estimated $\beta_{1}<0$ and is statistically significant, then our conclusion will be that remittances lowers growth volatility in our sample. However, if our estimated $\beta_{1}>0$ and is statistically significant, then our conclusion will be that remittance increases output growth volatility. $\mathrm{Z}$ as earlier defined is a matrix of the manage variables included in the model and their respective apriori expectations with respect to their impact on output volatility are discussed as follows:

i. If the capital flows are pro-cyclical, such that they generally tend to rise during improve economic conditions and fall during bad times, then they are capable to induce growth volatility therefore, we predict positive impact of capital flows on output volatility $(+)$.

ii. The impact of globalization on output growth volatility could be positive or negative $(+/-)$. For instance, openness can be associated with higher volatility because exports are fantastically concentrated and export prices are volatile (Rodrik, 1998). Then again, trade openness, rather than exposing countries to external shocks, can be a stabilizing factor with regards to domestic shocks (Easterly, Islam and Stiglitz, 2000).

iii. A larger percentage of government consumption in GDP can reduce volatility because government may work as a "safe sector" in the manner that the level of government employment and government purchase from other part of the economy is relatively stable (Rodrik, 1998). Alternatively, if government expenditures are rather pro-cyclical, then a larger $(G C O N)$ may increase growth volatility (Chami et al., 2008). To this end, the impact of GCON on output volatility could be negative or positive (+/-). 
iv. We expect $I N F L$ to induce growth volatility because inflation uncertainty can jeopardize the investment condition and make investment more volatile $(+)$.

To ensure that the empirical estimates from this study are compared with those in the literature that study the impact of remittances on output growth volatility, equation (1) will be estimated using three different estimation methods. First, the study estimates the impact of remittances on output growth volatility using the standard Ordinary Least Squares (OLS) method. However, estimating equation (1) using OLS raises several concerns as it fails to account for the potential endogeneity of the independent variables. One immediate hassle is that is correlated with the fixed results in the error term, which gives causes to dynamic panel bias (Nickell, 1981). Correlation among regressors and the disturbances violates an assumption necessary for the consistency of OLS and consequently OLS will yield biased and inconsistent coefficient estimates.

Two possible ways to work around this endogeneity are, one is to change the data to remove the fixed effects, which is tried by the second estimation method. The second method includes country specific effects and test which empirical model is most suitable for estimating economic growth. The Hausman test could be used to select the highest specification among the Fixed and Random Effects model. The other way to correct for the endogeneity hassle is by choosing a set of useful variables. The primary strategy in this study for mitigating the endogeneity problem is to estimate equation (1) by the use a panel system Generalized Method of Moments (GMM) technique. The GMM estimator is designed for situations with few time periods and many individuals and allows relaxing few of the OLS assumptions. As proposed by Arellano and Bond (1991), the first step in this estimation procedure is to eliminate unobservable heterogeneity $\left(\mu_{i}\right)$ by first differentiating equation (1).

$$
\Delta G P_{V O O_{i, t}}-\Delta G P_{V O_{i, t}}=(\beta-1)\left(G D P_{V O_{i, t}}-G D_{V O_{i, t-2}}\right) \beta\left(R E M_{i, t}-R E M_{i, t-1}\right)+Z\left(\gamma_{i, t}-\gamma_{i, t-1}\right)+\left(\varepsilon_{i, t}-\varepsilon_{i, t-1}\right)
$$

Equation (2) shows changes in output growth volatility to changes in remittances and the control variables. In the differentiated equation, there still exists the issue of correlation among the errors and the lagged dependent variable, which has to be corrected by instrumenting $G D P_{V O L_{i, t-1}}-G D P_{V O L_{i, t-2}}$. The validity of the GMM estimator relies upon the consistency of the moment conditions, which may be tested using two specifications tests. The first test is the Arellano-Bond test for autocorrelation, testing for no second order serial correlation in the disturbances. The second test is the Hansen (1982) J-test of over-identifying restrictions, is performed to ensure the validity of the instruments. The joint null hypothesis of the Hansen test is that the instruments are exogenous, i.e. unrelated with the error term, and that the excluded instruments are perfectly removed from the estimated equation. The Hansen test is used in place of the Sargan (1958) test of over-identifying restrictions because of its consistency when there is autocorrelation and heteroskedasticity (Roodman, 2009).

\section{Result and Discussion}

Table 2 below provides the estimated results of the panel regression models specified in equations (1) and (2). Columns one and two of Table 2 report Pooled OLS and fixed effects results of the static panel model. According to the Pooled OLS report, the main result of 
interest, which in this context is the impact of remittance on output volatility indicates that contrary to the study's apriori expectation, remittance rather appears to be inducing output volatility in ECOWAS. This notwithstanding, all control variables except of inflation rate (INFL) are statistically significant and have the expected sign. The Fixed Effects or Within Groups estimation model is chosen because the Hausman technique rejects the null hypothesis that both the Random Effects estimator and the Fixed Effects estimator are consistent. Again, all control variables with exception of inflation rate still have the expected signs; however, the coefficient assigned to remittance is though positive but the impact in this regard is insignificant. Column 3 of Table 2 reports two-step system GMM results. Two-step system GMM was chosen instead of one-step because the two-step estimator is asymptotically more adequate, with lower bias.

Table 2. Empirical estimates of static and dynamic panel models

\begin{tabular}{|c|c|c|c|c|c|c|}
\hline \multicolumn{7}{|c|}{ Dependent Variable: Output Growth Volatility } \\
\hline & \multicolumn{2}{|c|}{ Pooled Regression Model } & \multicolumn{2}{|c|}{$\begin{array}{c}\text { Fixed Effect } \\
\text { Model }\end{array}$} & \multicolumn{2}{|c|}{$\begin{array}{c}\text { System GMM } \\
\text { Model }\end{array}$} \\
\hline & Coefficient & Std. Errors & Coefficient & Std. Errors & Coefficient & Std. Errors \\
\hline Constant & $7.8298^{*}$ & 1.8113 & 15.9950 & 1.4553 & $1.9493^{*}$ & 0.9489 \\
\hline$G D P_{\operatorname{VOLT(-1)}}$ & & & & & $0.9939_{*}$ & 0.0127 \\
\hline$R E M$ & $0.3736^{*}$ & 0.0905 & 0.0099 & 0.0801 & $-0.0636^{* *}$ & 0.0318 \\
\hline CFLOW & $0.3529^{*}$ & 0.0365 & $0.0454^{* * *}$ & 0.0241 & $0.0833^{*}$ & 0.0099 \\
\hline GCON & $-0.3649^{*}$ & 0.0895 & $-0.3901^{*}$ & 0.0994 & -0.0270 & 0.0299 \\
\hline$I N F L$ & 0.0895 & 0.0369 & $-0.0456^{* * *}$ & 0.0254 & -0.0105 & 0.0137 \\
\hline TOP & $-0.0239^{*}$ & 0.0188 & $-0.0852^{*}$ & 0.0148 & $-0.0243^{*}$ & 0.0097 \\
\hline \multicolumn{7}{|c|}{ Diagnostic Test/Robustness Check } \\
\hline Countries & \multicolumn{2}{|c|}{18} & \multicolumn{2}{|c|}{18} & \multicolumn{2}{|c|}{18} \\
\hline Observation & \multicolumn{2}{|c|}{270} & \multicolumn{2}{|c|}{270} & \multicolumn{2}{|c|}{255} \\
\hline No. of Instruments & & & & & & \\
\hline R-squared & \multicolumn{2}{|c|}{0.411} & \multicolumn{2}{|c|}{0.205} & & \\
\hline F-statistic & \multicolumn{2}{|c|}{$36.85(0.00)$} & \multicolumn{2}{|c|}{$12.97(0.00)$} & & \\
\hline Hausman Test & & & \multicolumn{2}{|c|}{$19.35(0.00)$} & & \\
\hline $\mathrm{AR}(-1)$ & & & & & \multicolumn{2}{|c|}{0.029} \\
\hline $\operatorname{AR}(-2)$ & & & & & \multicolumn{2}{|c|}{0.317} \\
\hline Sargan Test & & & & & \multicolumn{2}{|c|}{0.164} \\
\hline Hansen & & & & & \multicolumn{2}{|c|}{0.133} \\
\hline
\end{tabular}

Source: Authors' Computation.

Note: $* * *$ and $* * *$ imply significant at $1 \%, 5 \%$ and $10 \%$ respectively.

All system GMM estimations are based on internal instruments only. The relevant diagnostics are recorded in the bottom of the table. To assess if the instruments employed are valid, 
autocorrelation and the Hansen tests of over-identifying restrictions are performed. The Hansen J-test tests the null hypothesis that the instruments are valid, not related with the error term. The Arellano-Bond technique for autocorrelation has a null hypothesis of no autocorrelation and is carried out to the differenced residuals. The test for AR (1) process in first differences always rejects the null hypothesis, but the test for AR (2) in first differences is essential due to the fact that it will detect first-order autocorrelation in levels. It is shown in table 2 that the tests for AR (2) fail to reject the null hypothesis of no autocorrelation.

In addition, the Hansen technique fails to detect any problem with instrument validity as the p-value for the Hansen test is higher than the conventional 5 percent level but not as high as 1.000. The instruments therefore seem to be valid and informative. Moreover, all diagnostic tests show that the model is correctly instrumented and estimated coefficients are reliable for inference. The results shown in column 3 of Table 2 also imply that manage variables like lagged of output growth volatility, capital flow, government consumption, inflation and trade openness appear with the correct sign and are consistent with theory. Essentially thus, the negative and statistically significant coefficient of remittance is an implication that influx of remittance to ECOWAS is altruistic motivated and as such it is important to stabilize output volatility in the region. Alternatively, the direct impact of government consumption or expenditure and inflation on output growth volatility appears to be nil given the insignificant of their respective negative impacts on output volatility. One the contrary, however, capital flow indicates the tendency of inducing output volatility significantly and the case is otherwise for trade openness.

\section{Conclusion and Policy Recommendations}

In order to ascertain or refute the popular assertion that remittance influx is altruistic in nature and as such reduces output growth volatility. This study explores both the static and dynamic panel estimation techniques to determine whether remittances inflow reduces output growth volatility in ECOWAS member countries. Drawing inference from the estimates based on the dynamic panel approach; we discover significant but inverse relationship between remittances and growth volatility with the case of ECOWAS for the period under consideration. While this is an indication that remittances inflow to the ECOWAS member nations are altruistic in nature. It further reaffirms the stability effect of remittances in the case of ECOWAS and it is thus, important for the concern authorities to encourage policies that would foster not only increasing influx of remittances to the region, but such that it would significantly stabilize volatility of any form in the region.

\section{References}

Ahamada, I., \& Coulibaly, D. (2011). How does financial development influence the impact of remittances on growth volatility? Economic Modelling, 28, 2748-2760. https://doi.org/10.1016/j.econmod.2011.08.019

Ajide, K. B., Raheem, I. D., \& Adeniyi, O. (2015). Output growth volatility, remittances and institutions. International Journal of Development, 14(3), 190-203. https://doi.org/10.1108/IJDI-06-2015-0039 
Becker, G.vS. (1974). A theory of social interactions. Journal of Political Economy, 82(6), 1063-1093. https://doi.org/10.1086/260265

Bettin, G., Presbitero, A. F., \& Spatafora, N. (2014). Remittances and vulnerability in developing countries. IMF Working Paper. https://doi.org/10.5089/9781484385081.001

Bugamelli, M., \& Paternò, F. (2005). Do workers' remittances reduce the probability of current account reversals? World Bank Policy Research Working Paper No. 3766.

Bugamelli, M., \& Paternò, F. (2008). Output growth volatility and remittances. Bank of Italy Working Paper No. 673. https://doi.org/10.2139/ssrn.1160173

Chami, R., Barajas, A., Cosimano, T., Fullenkamp, C., Gapen, M., \& Montiel, P. (2008), Macroeconomic consequences of remittances.IMF Occasional Paper No. 259.

Chami, R., Hakura, D. S., \& Montiel, P. J. (2012). Do worker remittances reduce output volatility in developing countries? Journal of Globalization and Development, 3(1), 1-25. https://doi.org/10.1515/1948-1837.1151

Craigwell, R., Jackman, M., \& Moore, W. (2009). Economic volatility and remittances: Evidence from SIDS. Journal of Economic Studies, 36(2), 135-146. https://doi.org/10.1108/01443580910955024

Easterly, W., Islam, R., \& Stiglitz, J. E. (2000). Shaken and stirred: Explaining growth volatility. In B. Pleskovic and J.E. Stiglitz, eds., Annual World Bank Conference on Development Economics 2000.

Funkhouser, E. (1995). Remittances from international migration: A comparison of E1 Salvador and Nicaragua. The Review of Economics and Statistics, 77, 137-146. https://doi.org/10.2307/2109999

International Monetary Fund. (2005), World Economic Outlook: Globalization and External Imbalances, World Economic and Financial Surveys, IMF, Washington, DC.

Lucas, R. E. B., \& Stark, O. (1985). Motivations to remit: Evidence from Botswana. Journal of Political Economy, 93(5), 901-918. https://doi.org/10.1086/261341

Neagu, I., \& Schiff, M. (2009). Remittance stability, cyclicality and stabilizing impact in developing countries (World Bank Policy Research Working Paper No. 5077). Retrieved from http://elibrary.worldbank.org/content/workingpaper/10.1596/1813-9450-5077

Ramey, G., \& Ramey, V. A. (1995). Cross-country evidence on the link between volatility and growth. The American Economic Review, 85(5), 1138-1151.

Rodrik, D. (1998). Why do more open economies have bigger governments? Journal of Political Economy, 106, 997-1032. https://doi.org/10.1086/250038

Stark, O. (1991). The Migration of Labor, Blackwell, Oxford and Cambridge, Mass (1991).

World Bank. (2013). Migration and Development Brief 21. Retrieved from http://siteresources.worldbank.org/INTPROSPECTS/Resources/334934-1288990760745/Mig 
rationandDevelopmentBrief21.pdf

\section{Copyright Disclaimer}

Copyright for this article is retained by the author(s), with first publication rights granted to the journal.

This is an open-access article distributed under the terms and conditions of the Creative Commons Attribution license (http://creativecommons.org/licenses/by/3.0/). 